\title{
Development of Modern Plant Protection Products: Why and How
}

\author{
Daniel Bellus*
}

\begin{abstract}
The future success of plant protection business depends to a great extent on the acceptance of the new generation of plant protection agents by both the market and the public. Accordingly, the complex development process in Ciba-Geigy fully reflects the requirements of Integrated Pest Management (IPM) and the principle of maximal carefulness for farmers (users), consumers, and the environment. Some basic facts on the necessity of plant protection measures, on IPM, biological and chemical pest control, possible contributions of biotechnology, the position of Ciba-Geigy in plant protection, and stages of the development of a new plant protection product from the discovery up to a successful market introduction are briefly presented and commented on.
\end{abstract}

\section{Introduction}

The search for new plant protection agents and their costly development to competitive commercial products is a fascinating task for chemists, biochemists, biologists, and agronomists in industrial agricultural research. They wish to play their part in the formation of new, safe, and ecological plant protection in the multifacetted interplay between technical possibilities, social expectations, economic conditions, and ecological demands. A detailed description of the enormously complex development process of a new plant protection agent at Ciba-Geigy would take up more space than the whole of this edition of Chimia [1]. Therefore, the way forward for a new plant protection agent from its conception and discovery to its launching on the market will be illustrated only in terms of general steps and by means of a few of our figures. Before doing it, some broader, more basic remarks about

- the global need for plant protection agents - Integrated Pest Management (IPM)

- the role of Ciba-Geigy in plant protection

will be presented. In this paper, it is intended to place future directions of research and possibilities for solutions in proper perspective, thus helping the interested reader to distinguish between vision and illusion in plant protection [2].

\section{Why Plant Protection? A Global View}

The agriculture of the world needs reliable crop protection. Progress in the productivity of modern agricultural systems is unthinkable without plant protection measures. An expert study published in 1990 [3] is quite definite about this. If chemical mea- sures to protect harvests against damage by insects, fungi, and weeds were not taken, agriculture in the USA would suffer the following losses of yield:

$\begin{array}{ll}\text { Maize } & 25 \% \\ \text { Soya } & 27 \% \\ \text { Wheat } & 21 \% \\ \text { Rice } & 68 \% \\ \text { Cotton } & 72 \%\end{array}$

Similar losses would be expected in other countries. Subtropical and tropical regions would definitely suffer far bigger losses.

It is an illusion to think that these losses can be compensated for by the cultivation of land reserves (there are hardly any left). As early as 1983, the FAO (Food and Agriculture Organisation of the United Nations) degradation' [4] warned that more cultivable land had been lost through soil degradation than the amount of land then in agricultural use (world-wide, 1439 million ha or 0.28 ha per head of population).

Every year, in addition to the land used in urbanisation, 5-7 million ha are lost to agricultural production through improper use of land. Felling tropical rain forests is no solution either, since these soils soon degrade and yield no more harvest [5]. The cultivable land per head of population will continue to decline:

in the year 2000 to 0.23 ha

in the year 2050 to 0.15 ha

in the year 2100 to 0.14 ha

assuming the world population has stabilised by that point.

We shall see that pressure to increase agricultural productivity, particularly in developing countries, will intensify as we move into the next century. The world population report 'Guidelines for the control of soil

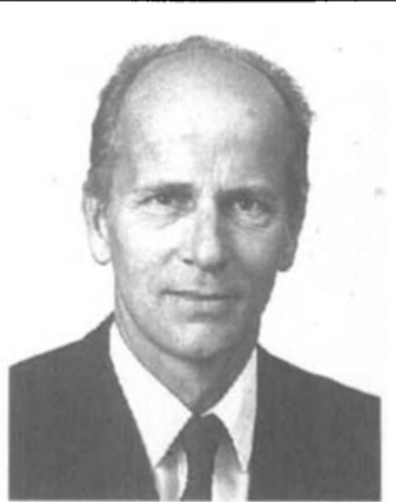

Daniel Bellus: Born 1938 in Trnava, Czechoslovakia. After studying chemistry (organic and pharmaceutical chemistry) at the Slovak Technical University in Bratislava, he carried out his doctoral research in the laboratories of the Polymer Institute of the Slovak Academy of Science in Bratislava. After one and half years (1967-9) of post-doctoral studies at the ETH, Zürich (organic photochemistry with Prof. O. Jeger and Prof. K. Schaffner) he joined the Exploratory Research Laboratories of $J . R$. Geigy in Basel. In 1981 he became Head of these Laboratories, now renamed the Central Research Laboratories of Ciba-Geigy, in Basel, and, in 1985, Head of the Research and Development Department of the Agricultural Division. In the meantime, he spent 6 months at Ciha-Geigy's Research Laboratories in Manchester, UK (1972), two years as the Head of the Department of Fluorescent Whitening Agents and Scintillators in the Dyestuffs and Chemicals Division of Ciha-Geigy' in Basel (1979-80) and three months as a Visiting Scientist at the Department of Chemistry and Biochemistry, M.I.T. in Cambridge, Mass., USA (1984). Since 1980, he has also lectured as a 'Professor titulaire' at the University of Fribourg.

will continue to expand. The World Bank expects a total increase from 5.3 billions in 1990 to 8.4 billions in 2025 . The overall population growth is not expected to level off completely until 2075, at 10-11 billions.

These conflicting trends point to a severe pressure on agricultural productive capacity in large parts of the developing world. But maintaining high crop yields/ha in our part of the world will also be imperative, e.g. to prevent further deforestation in other parts of the world, i.e. in subtropical and tropical countries, thus to avoid global warming-up. The only way out is the development of new cropping methods and vegetation management systems that keep the soil in good shape and give high yields per area unit.

One decisive factor in the achievement of this objective is the intelligent use of IPM compatible plant protection products (see next Sect.). In short, it is and will be a goal of any responsible research-oriented company to discover and to develop first-class products for the benefit of growers.

Many years of extensive and innovative agrochemical research have led to considerable improvements in terms of activity, selectivity, and environmental safety of plant

*Correspondence: Prof. Dr. D. Bellus

Plant Protection R\&D, Agricultural Division

Ciba Geigy AG

$\mathrm{CH}-4002$ Basel 
Table 1. Major Changes in Chemical Plant Protection

\begin{tabular}{lll}
\hline & 1960 's & 1990 's \\
\hline Active ingredient & simple structure & complex structures, natural products \\
Biological activity & broad, preventive & specific, curative \\
Application & calendar-based & when needed (IPM based) \\
Dose rates & $\mathrm{kg} / \mathrm{ha}$ & $\mathrm{g} / \mathrm{ha}$ \\
\hline
\end{tabular}

protection products (Table I) [6]. At the same time, standards and requirements for registration have steadily increased. Thus, overall safety for users of the products and consumers of agricultural produce has been largely improved, a fact which is often overlooked in public discussions.

Despite this generally very positive conclusion, there are problems connected with chemical plant protection. They are partly of a technical, partly of an emotional nature, for example:

Technical problems:

- the control of perennial weeds in annual crops,

- the control of wilt diseases and soilborne pathogens,

- the control of diseases caused by bacteria, mycoplasms, and viruses,

- the control of thrips in greenhouses and planthoppers on rice,

- resistance of pathogens, insects, and weeds to chemicals,

- the lack of tools for better targeted application.

Emotional problems:

- the fear of being gradually 'poisoned' by consuming chemically treated produce. Although the broad-ranging data shows a favourable residue situation on food crops and edible products, the public, which has to a large extent lost contact with nature and agriculture and their inherent rules, perceives chemicals as a health threat, despite steady increasing life expectancies.

- Society's concern that natural ecosystems and soil fertility will deteriorate with the use of chemicals, despite the well-known fact that agricultural ecosystems are degrading mainly because of the lack of protection against soil erosion, excessive deforestation, and unsuitable cultivation practices, and not from chemicals.

Even this short list of open topics would offer enough opportunities, challenges, and objectives for future research in plant protection. However, in a sense, this would only be a linear projection of the past, and we know from experience that this is a very imprecise guide to future developments. We have to consider additional factors, such as

- changed values, priorities, and requirements of society, especially concerning ecology and nature,

- new scientific and technical developments, such as asymmetric syntheses, measures: natural chemical products, genetic engineering, and new formulation and application methods,

- changes in agriculture in the direction of integrated crop production with IPM as an essential element.

\section{Integrated Pest Management (IPM)}

As well as traditional research goals such as high biological activity, low toxicity, crop tolerance, preservation of beneficials, or rapid breakdown in natural ecosystems, IPM is of central importance to our R\&D projects. Through intensive training and advice in many countries, we are trying to increase awareness of the IPM philosophy on the farmer level and put it into practice.

In company with the FAO, we see IPM as ecological, chronological, crop-specific and pest/disease-specific optimisation of four

l) mechanical and physical measures (e.g. how and when to sow, how to till),

2) cultivational measures (e.g. seed varieties, cover crops, crop rotations),

3) biological measures (e.g. pathogens, predators, bacteria, viruses)



Fig. 1. The four components of Integrated Pest Management (IPM)
4) chemical measures (i.e. synthetic and natural plant protection agents),

which are necessary to keep pest damage below the level of economic injury. The degree to which plant protection agents will be used varies according to the technical and economic feasibility and effectiveness of the other control measures (Fig. I).

As regards mechanical and physical measures, we are actively involved in the country- and crop-specific testing of our products, in recommendations on application, and in the development of application machines which minimise drift.

As regards cultivational measures, in the last decade plant biotechnology (improvement of plants by genetic manipulation) has often been touted overzealously and prematurely as a cure-all for a whole host of agricultural problems. This general lack of objectivity, combined with excessive speculation by venture capitalists who simply do not understand commercial agriculture, has led to heightened expectations. World-wide, there are about 500 companies and 150 research organisations that are active in agricultural biotechnology, and substantial amounts of money are invested in research.

Technologies that are based on cell cultures and molecular genetics might bear fruit in the medium term, perhaps in 10 years from now. Some genetically engineered plants resistant against attack from pathogens or especially insects and viruses can be expected. First scientific successes were reported with incorporated genes of Bacillus thuringiensis endotoxine. Reliable transfers, stable integration, and expression of useful genes have so far only been achieved in 
some dicotyledons. There are still many basic scientific problems to be solved in the case of monocotyledon varieties like wheat and maize. The results we achieved last year with the implantation of new genes in commercial maize varieties and their successful transfer to the next generation, therefore, signifies an encouraging breakthrough [7].

An objective assessment of long-term contributions of biotechnology to plant protection suggests that its contributions will be evolutionary, not revolutionary in nature. In each case, the seed becomes the carrier of the modified gene properties.

The third element in IPM are biological measures. Because of their nature, biological pest control agents are extremely targetspecific, and are generally expected to break down easily, with little negative impact on the environment. In closed production systems like greenhouses, islands, or big forest areas, with no or slow migration of infestation from outside areas, there are many examples of sufficient insect control by arthropod predators or bacteria. Biocontrol of pathogens and weeds is still in its infancy. It seems that product development takes much longer than expected due to technical disappointments and regulatory delays. The biocontrol market is estimated at $140 \mathrm{mil}$ lion SFr., which is presently $0.4 \%$ of the world-wide pesticide market. It is expected to grow $11 \%$ a year over the next 10 years. There are now large research efforts in academia and in industry, mainly in three areas: first, to increase the limited shelf life of biologicals by new types of formulation; second, to improve strains of microbes by biotechnology in order to obtain more consistent activity under field conditions, and third, to improve the economy of commercial-level production.

Evidently, the driving force for these research efforts is the perception of ecologically improved plant protection measures. One can envisage that, in the future, biologicals will and should be used whenever and wherever possible. However, replacing chemical-plant protection measures categorically, or even across broad areas of the market place, will not be easy. In millions of years, because of various types of selection processes in the nature, only those weeds, insects and pathogens with very few local natural enemies or which are superior to their enemies have survived and flourished.
There are, then, no effective natural enemies known for the worst weeds in world agriculture like Avena spp. (wild oats) in cereals and sugarbeets, Echinochloa crus galli Beauv. (barnyardgrass) in corn and Convolvulus spp. (bindweeds) in corn, fruits and grapes; insects like Diabrotica spp. (corn rootworms) in corn, Leptinotarsa decemlineata $\mathrm{S}_{\mathrm{AY}}$. (colorado potatoe beetle) in potatoes and solanaceae and Spodoptera spp. (leaf-and armyworms) in cotton and vegetables; and pathogens like Plasmopara viticola (downy mildew) in grapes; Cercospora spp. (leafspot diseases) in sugarbeets and peanuts, Septoria spp. (glume- and leafblotch) in cereals, Venturia inaequalis WINT. (applescab) in apples, and Botrytis cinerea (grey mold) in grapes, fruits, and vegetables.

These three valuable IPM elements will, in the foreseeable future need continued support from the fourth element of IPM, i.e. chemical products of synthetic or natural origin. The extent of their use will depend on agronomic, economic, and ecological suitability, and the efficacy of the other measures. Hopefully, this sober and realistic assessment of the chemical element of IPM

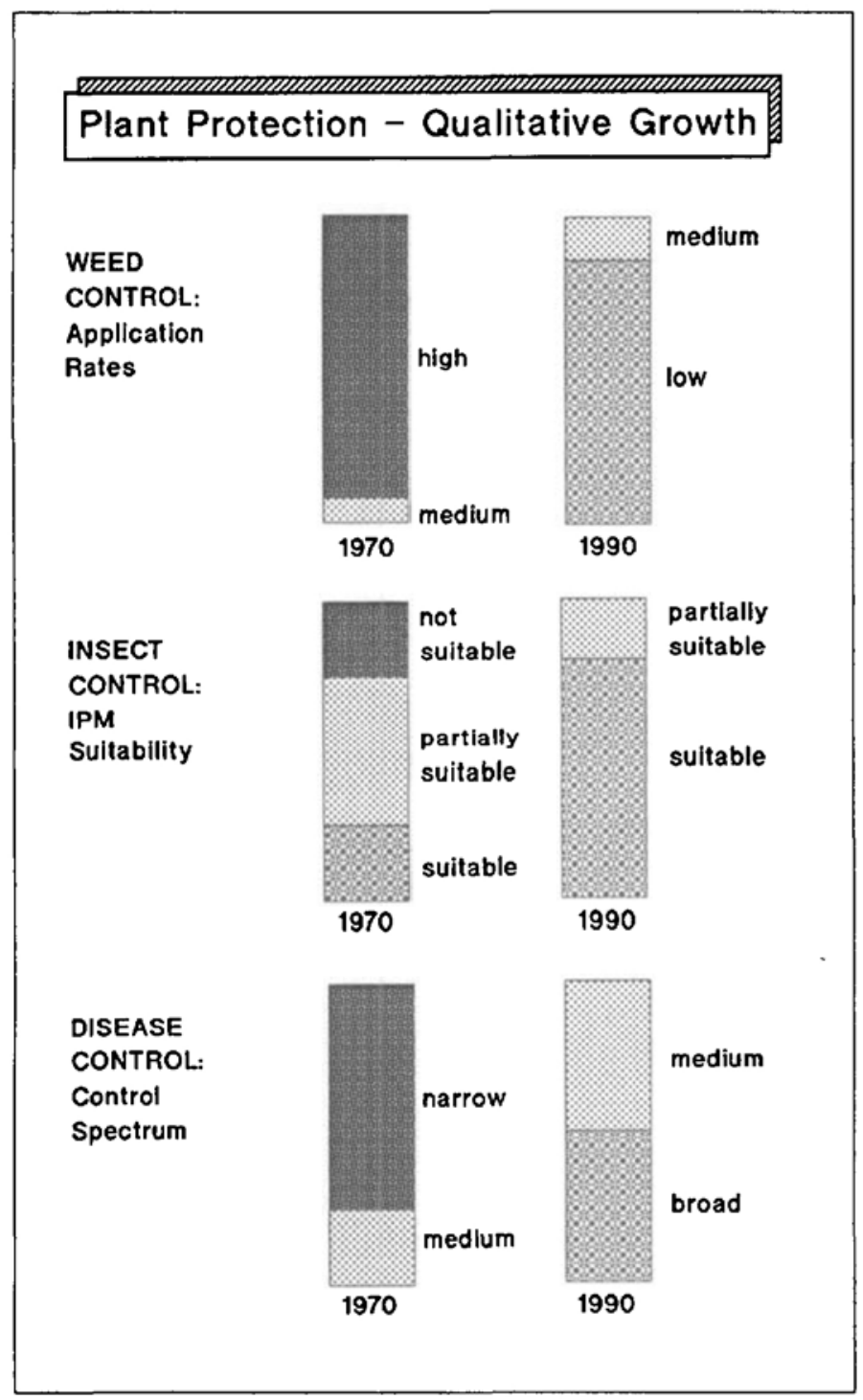

Fig. 2. Plant protection agents in Ciba-Geigy's development pipeline: 1970 vs. 1990. comparison of qualities

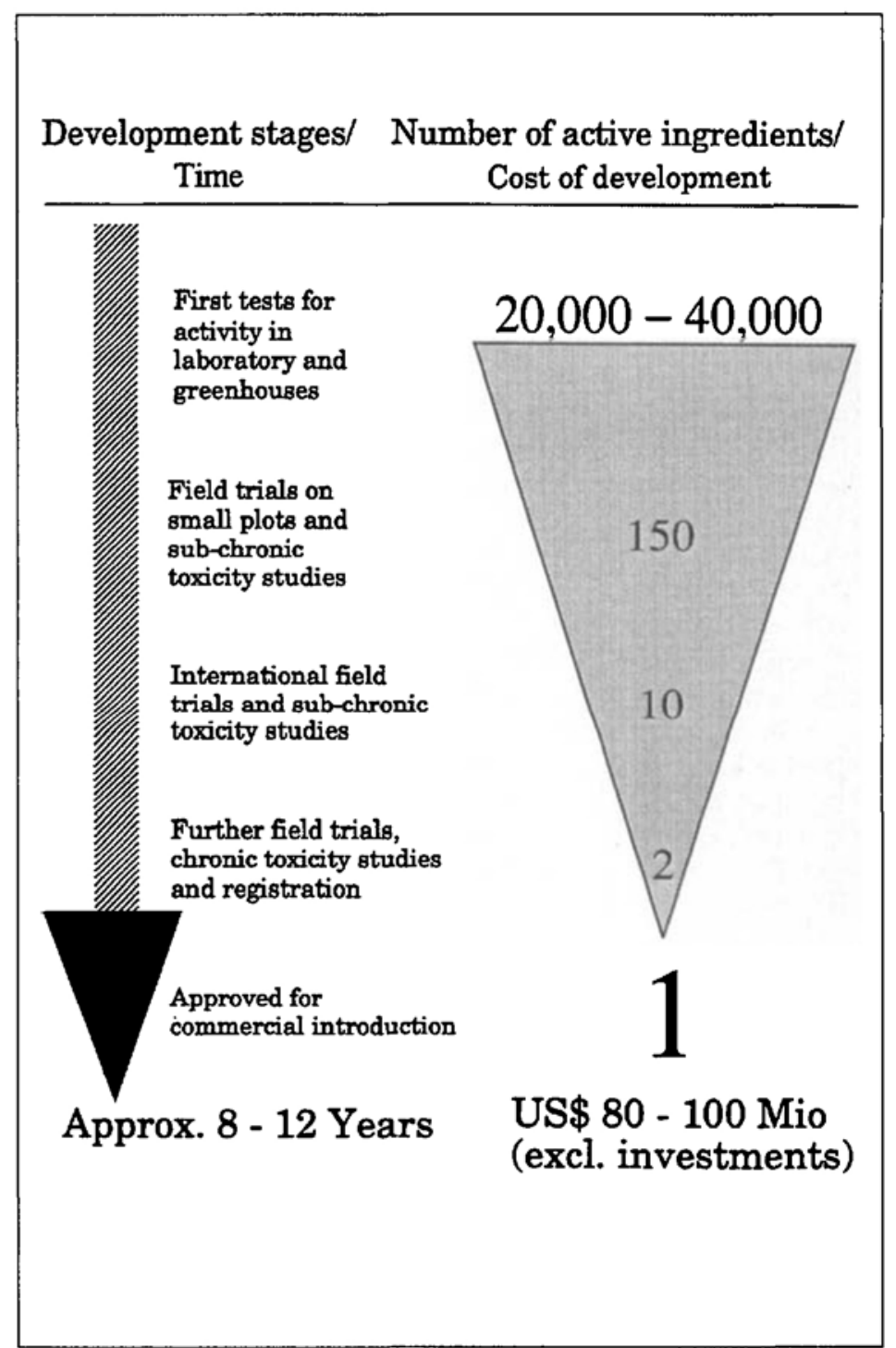

Fig. 3. Phases of development of a new plant protection agent from first screening to market introduction 
Table 2. Stages in the Development of a New Plant Protection Agent at Ciba-Geigy

\begin{tabular}{llll}
\hline $\begin{array}{l}\text { Stage } \\
\text { [years] }\end{array}$ & $\begin{array}{l}\text { Nr. of } \\
\text { compounds }\end{array}$ & Action \\
\hline 1 & 12,000 & $\begin{array}{l}\text { Research: synthesis, fermentation, biological tests } \\
\text { in a greenhouses, first tox studies. }\end{array}$ \\
2 & 120 & $\begin{array}{l}\text { Field tests: world-wide. Further tox and ecotox } \\
\text { studies. }\end{array}$ \\
3 & $2-3$ & 6 & $\begin{array}{l}\text { Development: biological, ecological, and economic } \\
\text { profiling of products with chances for the market. } \\
\text { Optimisation of the manufacturing process. }\end{array}$ \\
4 & $2-3$ & $\begin{array}{l}\text { Continuing field trials and safety evaluation all over } \\
\text { the world. First registrations. }\end{array}$ \\
5 & 1 & $\begin{array}{l}\text { Sales (R\&D: technical and agronomic support for } \\
\text { marketing and re-registration). }\end{array}$ \\
\hline
\end{tabular}

will soon prevail. In the past, the ease and reliability of chemical control has sometimes led to a neglect of other valuable elements of crop protection. Currently, chemical plant protection is facing a major problem, i.e. dealing with perceived problems of the nonagricultural elite of the developed western world. This is quite ironic, because plant protection agents under development and entering the market place today are safer than they ever have been (Fig. 2). It is felt that the only way to overcome this unfortunate bad image for our industry is to search for and develop even safer plant protection products (as described in the next two sections) and to keep the public, media people, and politicians adequately informed on our scientific progress and hopes.

\section{Plant Protection and Ciba-Geigy}

Ciba-Geigy has been the largest agrochemical firm in the world since 1987. It became market leader not through acquisitions, but through growth from within our strength in R\&D and marketing [8]. Last year, $45 \%$ of all the Agricultural Division's sales were accounted for by products that have been on the market for less than 10 years. This can be considered indicative of a good, innovatory climate in our company and the Agricultural Division. It also has its price, of course: in 1990, more than 2 billion SFr. were invested in R\&D in Ciba-Geigy as a whole, $10.4 \%$ of world-wide sales. In the Agricultural Division, this amounted to $12 \%$ of yearly sales.

Most of these costs are for the personnel employed in laboratories and field stations in 14 countries. Of these, $\mathrm{ca} .40 \%$ work in Switzerland. The requirements placed upon the complex development of a new plant protection agent from its discovery to its launching on the market are increasing, and the proportion of employees with academic qualifications is increasing, too: now $c a$. $35 \%$ of our employees are chemists, biochemists, biologists, agronomists, and even medical doctors; this in comparison to $23 \%$ 15 years ago.
As well as its material (money, facilities), intellectual (motivated expert employees), and organisational needs, successful, forward-looking R\&D must pursue clear aims and meaningful projects.

Although some biotechnologically improved seeds and a set of biologicals should appear on the market before the end of the millenium, we believe that, from a global perspective, chemical plant protection compatible with the other three IPM elements will play an absolutely central role in the next 20-40 years; the emphasis given to individual IPM measures could, however, vary geographically.

The leader in the market is also put under an obligation to fulfill a leading role in the development of modern plant protection agents which are compatible with the economic, social, and ecological expectations of broad sections of the public and which offer the farmer solutions which were not available before. The general direction of our research reflects current trends in plant protection and those to be expected in the future.

\section{The Development of a Plant Protection Agent}

In recent years, to bring one single modern plant-protection agent to the point, where it can be launched on the market, we have had to test an average of 12,000 new synthetic or natural compounds in a broad primary screen (stage 1, Table 2) against around 40 individual weeds, insects and phytopathological fungi. The figure of 12,000 is rather better than that repeatedly quoted for $R \& D$ in the agrochemical industry as a whole: 20,000 [9] (Fig. 3).

In terms of their origin, the compounds tested at stage 1 of so-called 'random screening' may basically be devided into four categories:

1. Specifically synthesised derivatives or analogues of known substances which are known to be highly effective (optimisation of the lead structures). This is at present the most productive route to new plant protection agents. E.g.,Ciba-Geigy's latest proprietary, low-rate weed control agents triasulfuron (1; for cereals), primisulfuron (2; for maize), and cinosulfuron (3; for rice) belong to the chemical class of sulfonylureas, whose herbicidal potency was first reported by $D u P$ ont $[10]$.

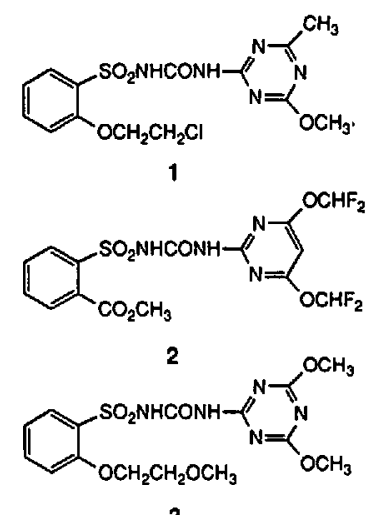

3

2. Compounds which were originally manufactured for other purposes, as pharmaceuticals, intermediates, etc. The discovery of successful substances in this category by 'random screening' is rare, but very rewarding, as they mostly show a new biochemical mode of action, and guarantee an unambiguous patent position as well. To this category of compounds belong inter alia our systemic fungicide metalaryl (4), the insect growth regulator cyromazine (5) and the safener oxabentril (6) [11].

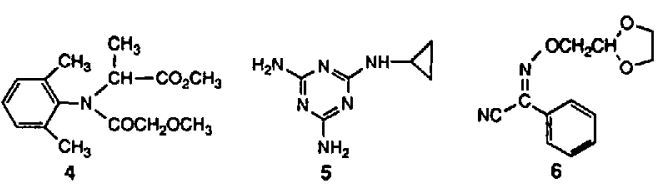

3. Compounds derived from nature [12], from fermentation (secondary metabolites) or from plants. To these belong also insect-specific pheromones, juvenile hormones, kairomones, neurotoxins, and plant growth hormones. Examples of this wide class of compounds include the macromolecular $\delta$-endotoxin from Bacillus thuringiensis [13]; the new pyrrole fungicides fenpiclonil (7) [14] and CGA 173'506 (8) [15], which are derived from the light-sensitive natural fungicide pyrrolnitrine (9); and the recently elucidated oviposition-deterring pheromone of the European cherry fruit fly (10) [16].




Table 3. Baxic Toxicology Data Requirements

\begin{tabular}{|c|c|c|}
\hline Test & Species & Duration [months] \\
\hline \multicolumn{3}{|l|}{ Acute } \\
\hline Oral/dermal/inhalation & Ral and rabbit & 3 \\
\hline Primary eye/dermal irritation & Rabbit & 3 \\
\hline Dermal sensitisation & Guinea pig & 6 \\
\hline Delayed neurotoxicity & Hen & 6 \\
\hline \multicolumn{3}{|l|}{ Subchronic } \\
\hline Range finding & Rat, mouse and dog & 3 \\
\hline 90 -day feeding & Rat, dog & 12 \\
\hline 28-day dermal & Rat & 6 \\
\hline 28-day inhatation & Rat & 6 \\
\hline \multicolumn{3}{|l|}{ Chronic } \\
\hline Chronic feeding/oncogenicity & Rat & 42 \\
\hline Oncogenicity & Mouse & 30 \\
\hline Chronic feeding ( 1 year) & Dog & 24 \\
\hline Teratogenicity & Rat and rabbit & 6 \\
\hline Reproduction, two-generation & Rat & 30 \\
\hline \multicolumn{3}{|l|}{ Mutagenicity } \\
\hline Gene mutation & Varies & 6 \\
\hline Chromosome aberration & Varies & 6 \\
\hline DNA damage and repair & Varies & 3 \\
\hline \multicolumn{3}{|l|}{ Special } \\
\hline Metabolism & Rat & up to 24 \\
\hline Dermal penetration & Rat & 6 \\
\hline
\end{tabular}

Table 4. Basic Environmental Data Requirements (see also [22]).

\begin{tabular}{lll}
\hline Test & Species & Duration (months) \\
\hline
\end{tabular}

Ecochemistry

Hydrolysis

Photodegradation (water, soil)

Soil metabolism (acrobic)

Aquatic melabolism (aerobic)

Leaching/adsorption-desorption

Volatility (laboratory)

Field dissipation (soil/water)

Long-term soil dissipation

Ecotoxicity

\section{$L C_{50}(48 \mathrm{~h})$}

Chronic study (21 d)

$L C_{50}(96 \mathrm{~h})$

Bioaccumulation

$E C_{301}$

$L D_{50}$ (acute \& $8 \mathrm{~d}$ )

$L D_{50}$ (oral \& contact)

$L D_{50}(14 \mathrm{~d})$

Nitrification/respiration

Metabolism in plants

Residues in plants

6
6
18
18
9
2
up to 15
up to 36

4. Compounds which interact only with those enzymes or polynucleotides that occur in pest organisms and no others, as far as possible. This 'biorational approach' to specific enzyme inhibitors is still in its infancy due to the current lack of knowledge about the majority of principal biochemical pathways in plants and insects. Nevertheless, remarkable progress has already been achieved in the field of transition state inhibitors and by the use of molecular modelling [17].
In previous years, biological activity, crop tolerance, and market profitability have been seen as the dominant criteria for promotion of a product to development stage 2 and especially stages 3 and 4 (Table 2). Nowadays, potential candidates undergo a thorough environmental, chemo-dynamic [18] and toxicological prescreening as early as in stages 1 and 2. Good candidates also should preferably have novel modes of action to avoid cross-resistance with established products, be applicable postemergently (weed control) or curatively (disease control), have low application rates, or be applicable as seed treatment. Thus, high compatibility of potential chemical product with other IPM measures is established at an early stage of the very costly development process (Fig. 3). If they occur, enantiomerically pure isomers are prepared and thoroughly tested [19].

Typically, development takes up 8-12 years and costs $120-160$ million SFr. by the time the new plant protection product is launched on the market. These figures are increasing, as our world-wide activities at every stage of development are constantly being brought up to date in terms of ecology, GLP (Good Laboratory Practice), anti-resistance strategy [20] etc., and thus become more complex. Whereas, e.g., a typical development product in 1973 could be manufactured in 3 synthetic steps, nowadays an average of 6.3 steps are needed. Whereas in 1972 only 81 documents and reports were needed for the world-wide registration of a plant protection product, so far 1,700 reports have been needed to register the broad-spectrum fungicide propiconazole across the globe (with an average thickness of $1 \mathrm{~cm}$ per report, this is equivalent to the height of a 5 storey building...).

In Ciba-Geigy's Agricultural Division, the budget for safety and registration research increased from $21 \%$ of the total R\&D budget in 1981 to $36 \%$ in 1989 - in absolute terms this represents a fourfold increase in expenditure. As a consequence of such tremendous effort, which presumably applies to the research-oriented agrochemical industry in general, there has been enormous progress in the quality of compounds that have entered our development pipeline since 1970 [21] (Fig. 2). Of course, we would like to introduce the most recently developed compounds onto the market as soon as possible. If it is thought that we in the agrochemical industry are being slow, it should not be concluded that this is the fault of the industry alone. We are living in an age of inverse logic: the public wants rapid introduction of environmentally more acceptable plant protection products, but the various authorities, which are elected by the same public, require incredibly stringent investigation of the new compounds, and this takes a long time.

It must be emphasised that bringing a new plant protection product from research to the market is one of the most difficult and 
costly challenges for business and industry today. No other group of products, except perhaps human pharmaceuticals, must undergo a more rigorous and exhaustive evaluation process. To illustrate this, the basic toxicological and environmental requirements for the registration of a new plant protection agent are summarised in Tables 3 and 4 . Not included, however, are the numerous country-, soil- and crop-specific studies and the frequent product-specific requests from regulatory authorities, which prolong the registration process further. Moreover, emphasis can differ from country to country. Food safety (residues) is a major criterion for the US Environmental Protection Agency (EPA); leaching into ground water is the main focus in Germany, however, and in Japan, fish toxicity.

Our responsibility does not end after the market launch (stage 5). The product stewardship during the life-time of a product consists of two main tasks: the maintenance of national registrations, and technical upgrading to comply with new user needs. The practical implications of this are e.g.:

- new package designs to reduce contamination and waste (water-soluble bags, refillable containers),

- targeted application techniques,

- refinement of application timing, e.g. by electronic monitoring for prediction systems or by the use of diagnostics, thus allowing a more rational use of products on a 'need to use' basis,

- new formulations, e.g. less leaching by slow release, microencapsulation,

- development of anti-resistance management strategies [20],

- continuous upgrading of safety information,

- avoidance of or improvement in disposal of leftovers and empty packaging,

- promotion of training for farmers in the use of plant protection agents,

- development of mixtures to rationalise plant protection measures (e.g. synergy effects; safening of herbicides),

- voluntary withdrawal of products not meeting safety standards.

The increased quality requirements of the authorities are welcomed, as long as they are objectively justified, apply to all manufacturers of plant protection agents, and are not misused for demagogic or political ends. We believe that it is only by using plant protection products of high quality (selective, acceptable for people and environment in terms of safety, rapidly biodegradable, applicable in small quantities) that the public at large will again be able to see that there is no contradiction between nature, chemistry, and biology.

\section{Conclusions}

All in all, the indications are that the strong and successful agrochemical companies of the future will be those which
- have comprehensive spectrum of chemical and biological products,

- have effective R\&D aimed at generating such products,

- are strong internationally,

- employ enthusiastic experts having confidence in the future,

- give high priority to ensuring that their products, when used as recommended, are safe to the user, the environment, and the consumer of the treated crop.

We are determined to stay leader of the agrochemical companies and would be very happy indeed if this or that problem of worldwide agriculture could be solved in a good, ecological way by new products from our R\&D. This would then be in perfect harmony with the Ciba-Geigy Vision: by striking a balance between our economic, social, and environmental responsibilities, we want to ensure the prosperity of our enterprise beyond the year 2000 .

Received: March 13, 1991

[1] Moreover, the expertise, methodologies and systems that have been developed and used in the interactive international Research and Development network, represent an extremely valuable proprictary know-how of our company.

[2] This paper is based on several plenary lectures presented by the author in 1990, especially at the Symposium of the Royal Dutch Chemical Society on April4 in Wageningen, Netherlands, at the 5th NOZAKI conference on May 31 in Okayama, Japan, and at the Chemistry Fair INCHEBA on June 27 in Bratislava, CSFR.

[3] 'The value of Crop Protection Chemicals and Fertilizers to American Agriculture and the Consumer', Report of Government Research Corporation Economics (GRCE), Washington, D.C., 1990.

[4] a) Guidelines for the control of soil degradation, FAO, Rome 1983; b) R. Lal, in 'Conservation tillage for sustainable agriculture: Tropics versus temperate environment', $A d v$. Agronomy 1989, 42, 85 .

[5] J.H. Reichholf, 'Der tropische Regenwald. Die Ökologie des artenreichsten Naturraumes der Erde', dtv-Verlag, München, 1990.

[6] Several researchers from Ciba-Geigy have recently published papers full of facts and encouragement with respect to these topics: a) 'Importance, possibilities and limitations of chemical control now and in the future - an industry view', F.J. Schwinn, Ecol. Bull. 1988, 39,$82 ;$ b) 'Innovation in the Plant Protection Industry; Requirements and Constraints', G. Voss, H. Geissbühler, in 'Pesticides and Alternatives', Ed.J.E. Casida, ElsevierScience Publ., Amsterdam, 1990, p. 3; c) 'Industry Achievements in Meeting the Needs of Society and Farmers for Modern Plant Protection', P.A. Urech, in Proceedings of Brighton Crop Protection Conference, 1990, Vol. 1, p. 283.
[7] S. Watts, New Scientist 1990, 127, 27.

[8] The first exception to this principle was made in August 1990 by acquiring the middle-sized company Dr. R. Maag AG, which contributed a number of interesting development and sales compounds to Ciba-Geigy's product portfolio. especially two outstanding cereal fungicides, fenpropimorf 11 and fenpropidin 12.
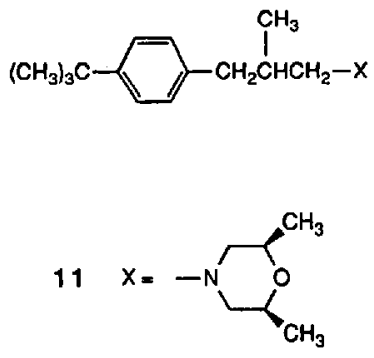

12

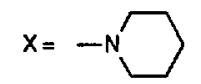

[9] Ch. von Szczepanski, in 'Recent Advances in Chemistry of Insect Control Il', Ed. L. Crombie, Royal Society of Chemistry, Cambridge, 1990, p. 1.

[10] J.V. Hay, Pestic. Sci. 1990, 29, 247, and ref. cit. therein. See also: W. Iwanzik, Landwirtschaft Schweiz 1990, 3, 17.

[11] For details of their biological activity, see 'The Pesticide Manual, A World Compendium?, 9th edn., Ed. C.R. Worthing, published by The British Crop Protection Council, Farnham, 1991; as well as (for 6) E. Ebert, H.R. Gerber, in 'Crop Safeners for Herbicides', Eds. K.K. Hatzios and R.E. Hoagland, Academic Press, San Diego, 1989, p. 177.

[12] a) H.-P. Fischer, Nachr.Chem. Tech Lab. 1990, 38,732 , and ref. cit. therein; b) 'Biologically' Active Natural Products: Potential Use in Agriculture', Ed. G. Cutler, ACS Symp. Series $1988,380$.

[13] a) A. Krieg, 'Bacillus thuringiensis, ein mikrobielles Insektizid', P. Parey Publ., Berlin, 1986; b) B.B. Spear, ACS Symp. Ser. 1987. 334, 204; c) A.R. Jutsum, N.J. Poole, K.A. Powell, in 'Progress and Prospects in Insect Control', Ed. N.R. MeFarlanc, The British Crop Protection Council, Farnham, 1989, p. 131.

[14] R. Nyfeler, T. Egli, D. Nevill, in Book of Abstracts, 7th Int. Symposium of Pesticide Chemistry, Eds. H. Frehse, E. KesselerSchmitz, and S. Conway, GDCh, Hamburg, 1990, Vol. 1, p. 219.

[15] E. Gehmann, R. Nyfeler, A.J. Leadbeater. D. Nevill, D. Sozzi, in Proceedings of the Brighton Crop Protection Conference 1990, Vol. 1, p. 399.

[16] B. Ernst, B. Wagner, Helv'. Chim. Acta 1989, 72,165 , and ref. cit. therein.

[17] a) H. Huxley-Tencer, E. Francotte, M. Bladocka-Moreau, Pestic. Sci. 1991, in press; b) Book of Abstracts, Vol. 1, cited in ref. [14]. p. 165.

[18] K. Gubler, Ch. d'Hondt, A. Steinemann, Proceedings of the 31st Int. Congress of Pure and Applied Chemistry (IUPAC), Sofia 1987. Pergamon Press, Oxford, p. 126; A. Steinemann, E. Stamm, B. Frei, Aspects Appl. Biol. 1989, 2l, 203.

[19] G.M. Ramos Tombo, D. Bellus, review on 'Chirality and Plant Protection', submitted to Angew. Chem.

[20] G. Voss, Pestic. Sci. 1988, 23, 149

[21] For additional information, sec also: D. Bellus, in 'Bioactive Compounds from Plants', Ciba Foundation Symposium 154, Eds. D.J. Chadwick and J. Marsh, Wiley \& Sons, Chichester, 1990, p. 94.

[22] H.O. Esser, R.J. Hemingway, W. Klein, D.B. Sharlp, J.W. Vonk, P.T. Holland, Pure Appl. Chem. 1988, 60, 901 . 